\title{
Grass-roots examination of resources to leverage for a robust outreach program
}

P. Griffiths, E. El-Kareh, D. Fong, H. Black, R. Dahlgren, et al.

P. Griffiths, E. El-Kareh, D. Fong, H. Black, R. Dahlgren, S. Sukuta, P. Doherty, P. Grossi, D. Walker, J. Becker, C. Monroe, R. Farnsworth, B. Schmahl, R. Filson, T. Tarter, "Grass-roots examination of resources to leverage for a robust outreach program," Proc. SPIE 9663, Eighth International Topical Meeting on Education and Training in Optics and Photonics, 96631H (6 October 2003); doi: 10.1117/12.2208466

SPIE Event: Eighth International Topical Meeting on Education and Training in Optics and Photonics, 2003, Tucson, Arizona, United States 


\title{
Grass-Roots Examination of Resources to Leverage for a Robust Outreach Program
}

\author{
P. Griffiths ${ }^{1}$, E. El-Kareh ${ }^{2}$, D. Fong ${ }^{3}$, H. Black ${ }^{4}$, R. Dahlgren ${ }^{5}$, S. Sukuta ${ }^{6}$, P. Doherty ${ }^{7}$, P. Grossi ${ }^{8}$, \\ D. Walker, J. Becker, C. Monroe ${ }^{9}$, R. Farnsworth ${ }^{11}$, B. Schmahl ${ }^{12}$, R. Filson ${ }^{13}$, and T. Tarter ${ }^{14}$ \\ Optics-Ed Steering Committee: ${ }^{1}$ OSNC, ${ }^{2}$ IPC, ${ }^{3}$ IEEE SCV ExCom, ${ }^{4}$ ESUHSD, ${ }^{5}$ SCV LEOS, ${ }^{6}$ SJCC, ${ }^{7}$ The Exploratorium, \\ ${ }^{8}$ RAFT, ${ }^{9}$ SJSU, ${ }^{10}$ SVEC, ${ }^{11}$ LLNL, ${ }^{12}$ Schmahl Science, ${ }^{13}$ CSTA, and ${ }^{14}$ SCVCPMT optics-ed-com@ieee.org
}

\begin{abstract}
An ad-hoc group of has "self-assembled" in the Silicon Valley for the purpose of generating the wonder and excitement of science in young people, via optics. A systematic approach to science outreach is presented, and sample projects will be described, such as the Science NanoGrant project.
\end{abstract}

\section{Summary}

The San Francisco Bay Area is home to many technical societies; two active photonics groups are the Santa Clara Valley Chapter of the IEEE Laser \& Electro-Optics Society, and the Optical Society of Northern California (a local chapter of the Optical Society of America). These two groups, along with IEEE veterans and high school science coordinators and instructors formed an ad-hoc committee in response to a newspaper article that described a shortage of supplies for middle school and high school science classrooms [1]. Upon the first meeting in 1999, the engineers were surprised to learn that in such prosperous times, Silicon Valley schools sought batteries and paper towels and not lasers and fibers! An email reflector and web site was established [2] which facilitated this kernel called Optics-Ed evolving to over 100 like-minded individuals governed by an Optics-Ed steering committee (OESC). Email and face-to-face meetings established a succinct philosophy for a robust outreach program. Entities such as science museums, foundations, individual engineer-volunteers, $3^{\text {rd }}$-party facilitators, distributors, teachers, science fairs, and garage science workshops all brought great things to the table, and a framework for interaction was created to facilitate linkage and avoid duplication of effort. As networking continued the members were also surprised, albeit pleasantly so, to find significant grass-roots support for science activities - but rarely was the connection made between the source of a given resource and all of the end users of that same resource. At the time of this writing, the Optics-Ed philosophy is:

- What is desired is a scalable, sustainable, affordable, outreach program with continuity.

- Seek and listen to grass-roots members - leveraging existing, successful entities whenever possible.

- Entities were classified into sets: (1) Users, (2) Programs, (3) Volunteers, and (4) $3^{\text {rd }}$-parties.

- Understand and summarize the resources each entity would source and/or sink, connect the dots.

- Make the system flexible and asynchronous, with low or no overhead. Assume no paid staff.

- Obtain free content, rigorously qualify, and circulate through 3rd party distributors, not volunteers.

- Implement database, oversight, and continuous improvement mechanisms.

Optics-Ed implemented the following: (A) a portion of an existing 501(c)3 bank account to enable tax-deductible cash donations; (B) obtain high quality, free content; (C) these and other resources are pooled and made available to end-users at no charge; (D) the "catch" for teachers is feedback. For example, an account was established at Radio Shack $^{\mathrm{TM}}$ and has been endowed via tax-deductible donations to the 501(c)3 account. Teachers may apply for a "Science NanoGrant", which is good for up to $\$ 10.00$ of science-related items by filling out an electronic form. In this manner, permanent entities, not individual volunteers handle money, inventory and distribution. A similar project envisions buying optics kits and re-donating them to a distributor such as Resource Area for Teachers (RAFT), which would handle storage, circulation, maintenance of the kits and teacher training.

\section{References}

1. J. Rodriguez, "East San Jose schools need resources to develop science fair project" San Jose Mercury News, (April 28, 1999)

2. For more information, see http://www.ewh.ieee.org/r6/scv/k-12/optics.html

Eighth International Topical Meeting on Education and Training in Optics and Photonics, edited by Barry L. Shoop, Grover Swartzlander Jr., Proc. of SPIE Vol. 9663, 96631H

(C) 2003 SPIE, OSA, ICO · doi: 10.1117/12.2208466 